\title{
Divergent Pasts, Parallel Futures? Between Competition and Co-operation in the Argentinian, Chilean and New Zealand Wine Sectors
}

WARWICK E. MURRAY and JOHN OVERTON

\section{Introduction}

The world of wine is frequently cast in terms of a distinction between the Old World (the producers of Europe) and the New World (those in USA, Australasia, South America and South Africa). Although this is somewhat of a false dichotomy, ${ }^{1}$ it does suggest that New World wine is qualitatively different from the Old; it is less constrained by tradition and regulation and it is characterized by modern methods of production. Furthermore, New World producers - many situated on the periphery of the global economy - compete with one another on export markets, differentiating their products on the basis of price and style. In this context, New Zealand wine producers face stiff competition from Chile and Argentina, as they do for a range of commodities that they produce in common, such as fruit and forestry products. ${ }^{2}$

At first glance the wine industries studied here seem quite different. In a quantitative sense the three wine sectors are set apart. Argentina has a relatively large population approaching 40 million and this domestic market for wine explains why exports remain relatively unimportant there. In Chile with a population closer to 20 million, the domestic sector is important. Export orientation has been seen as a necessary strategy to break out of the confines of the domestic market and the wine sector represents a very clear example of such a strategy. In relative terms New Zealand is small with a population of just under four million and, although income per capita is significantly higher, its relatively diminutive size means that export orientation has played a central role in the evolution of the sector. Thus, the wine industries of the three countries operate at different scales.

Faced with different factor endowments in both an absolute and relative sense, the three countries have had to seek out ways of differentiating 
their wine on the world market. Although their economies inhabit similar competitive spaces in the global economy, this has not necessarily meant that they have clashed directly for market access. Instead we have seen the evolution of a strategy in the wine sector, and others, ${ }^{3}$ that resides somewhere between co-operation and competition where niche positioning has become a dominant strategy. This paper traces the trajectories of change in the wine industries of Argentina, Chile and New Zealand and shows that, despite divergent historical roots, the three economies now exhibit increasingly parallel sectors which actively target globally competitive, yet nonoverlapping spaces. In this sense, we argue there may be further synergies to be gained in cooperation rather than competition on the periphery of the global wine sector. This contention may bear broader implications that can be applied in other sectors and economies in the semi-periphery.

\section{Divergent histories of wine production}

At first sight, there is a major contrast in the history of wine production of Argentina and Chile on one hand and New Zealand on the other. The former have had a strong wine producing heritage lasting some 500 years, whereas New Zealand wine was virtually absent for the first 120 years of European settlement. As noted previously, despite these vast differences in their histories as well as their relative sizes, in the past 30 years the industries of the three countries have converged in some significant ways.

Wine production followed closely on the heels of the Spanish colonizers of South America and found particularly favourable conditions in what became Argentina and Chile. Grapes were grown and wine produced on many estates in these two countries from the sixteenth century onwards. It was a largely domestic product, produced on a small scale on estates and smallholdings alike and consumed on or close to its place of production. Exports were minimal, production techniques rudimentary and commercialization of the industry limited. For many, wine was a household subsistence product. The varieties of grapes grown descended from the Spanish colonizers and included País and Muscatel in Chile - varieties which grew throughout the regions of both countries.

Although wine production in Chile and Argentina remained in this condition for much of the period from the sixteenth to the mid-twentieth centuries, some important changes did take place. In Chile the arrival of Basque and Huguenot settlers in the nineteenth century - and in Argentina, French and Italian migrants at the same time - led to the introduction of more classical European grape varieties from pre-phylloxera France: ${ }^{4}$ varieties such as Cabernet Sauvignon, Merlot and Chardonnay which were later to become the mainstays of the industry. Some of these immigrants also had a more commercial orientation with their production and founded 
companies such as Ruttini in Mendoza. They began to tap the growing domestic market for wine in the expanding towns and cities.

As the industries expanded in the two countries into the second half of the twentieth century, they conformed to the structuralist economic philosophies of the time with a strong emphasis on import substitution industrialization. Wine was a product that could be produced locally and satisfy local demand, obviating the need for foreign imports. Production was often on a large scale. Wineries such as Trapiche in Mendoza had large industrial-scale factories producing wine in bulk that was railed to centres such as Buenos Aires and sold cheaply as a common consumption item for urban dwellers. Such wine did include the classical varieties, such as Cabernet Sauvignon, but was more often produced using the old-established varieties packaged in barrels or large glass containers and as generic red and white (mixed variety) wines. ${ }^{5}$ Economies of scale and low-cost undifferentiated mass products characterized an industry very closely wedded to a protected domestic market.

New Zealand, by contrast, had a quite different and much less venerable wine industry. Early missionaries and traders tried grape growing from the first days of European settlement in the nineteenth century. However, for most of the country's European history, wine production and consumption faced several formidable obstacles including hostile competition from brewing firms and opposition from temperance groups which restricted the sale of locally produced wines. ${ }^{6}$ Only in the 1970 s did a local industry begin to emerge when a number of companies (notably several from Australia) saw the potential to sell wine (including fortified brands such as 'port' and 'sherry') made from local grapes. This nascent industry was oriented solely towards a domestic market that had very low rates of wine consumption (compared to beer and spirits) and what it produced were cheap bulk products that derived from high yielding often hybrid varieties of grape. Although popular at the time as an alternative alcoholic beverage, these wines tended to be sweet and falsely modelled on European brands such as 'Hock', 'Moselle' or 'Burgundy' even though their constituent grapes (much less the resultant wines) bore little resemblance to their European originals. Sweeter-style white wines, especially made from the Müller Thurgau variety, dominated the market, often being sold in three litre casks, just as fortified wines came in half gallon bottles.

By the late 1970s, therefore, the three countries had begun to converge, even though New Zealand had a much smaller scale and much more recent wine industry. All three had settled on a formula that focused on the domestic market - exports were minimal - and low-cost, high-volume production of relatively undifferentiated bulk wine that competed not against European wine but against local beer and spirits. 
Change came in a dramatic fashion in the 1980s and changed the histories of all three countries' wine industries in a similar way. The change resulted from the adoption of neoliberal policies in dramatic fashion in each of the countries. This shift came first to Chile following the military coup of 1973 led by Pinochet. In ousting the socialist coalition the junta soon reversed the structuralist and dependency-inspired policies of Allende and replaced them by 1975 with a series of reforms that converted Chile into the most open economy in the world. In the rural areas an agrarian counter-reform divided up collective land holdings and returned them to former large-scale owners. The complete elimination of agricultural subsidies led to harsh competition in the countryside. This led to significant re-orientation of production towards external markets. Based on low labour costs, precipitated by deregulation in the labour market, Chilean wine competed based on price in the global market and began to carve a low-quality niche in that regard. Neoliberalism was compounded in the 1980s in Chile after the crisis of 1982 and the export model continued to dominate. By this time many smaller-scale farmers had been out-competed with large-scale, hacienda-type properties evolving where the Chilean wine industry had become increasingly concentrated.

Of the three countries discussed here the shift to neoliberalism came later and was less enduring in the case of Argentina. Influenced by structuralist ideas, Peronism principally dominated until 1976 when a coup removed Eva Peron as president. The military enacted some deregulation but the reforms were in no way as complete as they were in Chile. The return to democracy following the fall of General Galtieri in 1983 paved the way for the democratically-elected administration of Alfonsín which enacted a number of policy shifts based on IMF insistence. These had devastating impacts in the countryside. In Argentina initial neoliberal restructuring was deeply unpopular and the eventual currency crisis of 1989 led to the replacement of Alfonsín by the more overtly neoliberal Menem. Menem was a Peronist but his privatizations and free market reforms were intended to model the outward orientation of the newly democratic Chile where growth had been rapid. The Argentinean economy became increasingly export-oriented and this had an impact in the wine sector which declined in the newly-opened competitive landscape.

In Chile and Argentina, the decline brought about by neoliberalism in the wine sector in the 1980s was apparent. Local industries were outclassed in terms of higher quality and more diversified imports and the strategy of exports based on low labour costs and hence price gave both industries a poor international reputation. In Argentina in particular, local production began to fall and the area planted in vineyards dropped, whilst in Chile it, at best, stagnated. Unlike New Zealand, wine in Chile and Argentina could survive in the face of competition from imports, for local production costs 
remained very low but, without government protection and subsidies, it was forced into a lowly position in the market with tight margins and changing consumer preferences towards higher quality more expensive wines. Figure 1 shows the changes in area under vineyards in the three countries. For New Zealand, there was a slight dip in the late 1980s before some recovery but in Argentina the decline in area extended well into the next decade.

Figure 1: Surface area under vineyard, 000s hectares, Argentina, Chile and New Zealand 1986-2007

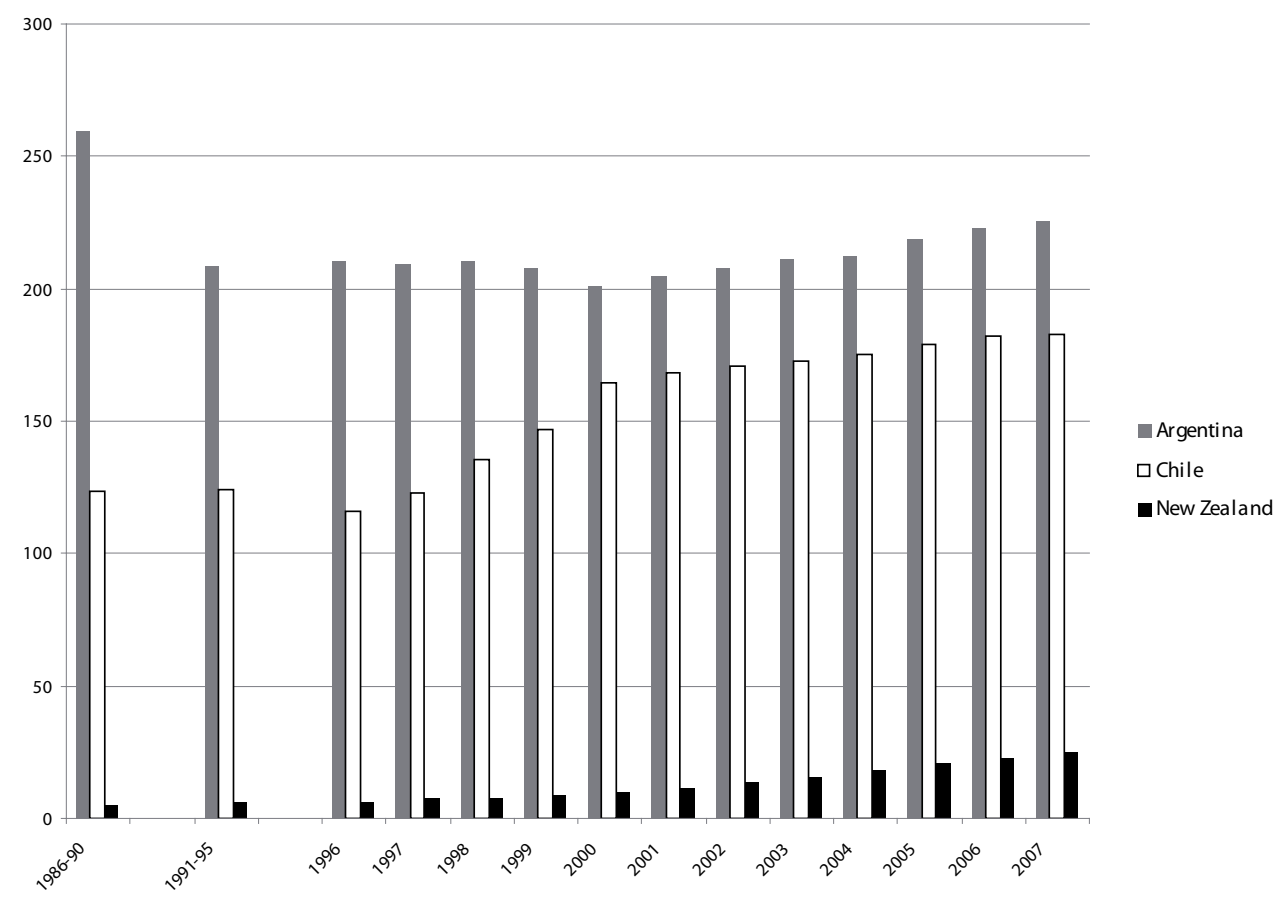

Source: OIV (2011), also Overton and Murray (2011), see note 17.

In New Zealand the move to neoliberalism came with a suddenness that matched the other two - although it was marked by the difference that it took place under democracy rather than dictatorship. In late 1984, the former Muldoon administration (which had stuck to strong protectionist policies and economic regulation) was replaced by the Lange Labour government. The incoming administration quickly introduced widespread economic reforms that ended most forms of government protection for agriculture, lowered import tariffs, and floated the exchange and interest rates. The immediate 
result was a crisis for the rural sector with land values falling. For the wine industry it was equally traumatic. Imports of wine, especially from Australia, introduced consumers to wine that was both different, better and yet just as cheap. Local wines struggled. An even greater crisis for the industry that had hit the dairy and livestock sectors was partially averted when the government sponsored a 'vine-pull' scheme in 1986, paying grape growers to uproot their vines and seek alternative crops. ${ }^{7}$ The New Zealand wine industry seemed poised for substantial decline, even oblivion.

\section{Recovery and the new neoliberalism \\ - value-added export orientation}

What saved the wine industries of the three countries was a similar, though slightly differently-timed and structured, turn away from domestic orientation based on price to export orientation which sought to add value through quality and specialization. ${ }^{8}$ This has been termed 'upgrading' by several authors. ${ }^{9}$ In some ways this can be conceptualized as a second phase in neoliberal restructuring once the impacts of the 'easy' large scale bulk export phase had been exhausted. Some have characterized this policy adjustment as a shift towards neostructuralism, whereas others have termed it an adjustment necessary to perpetuate the neoliberal mode of accumulation. In the wine industry the need to move beyond low-cost activity came only when it was realized that much of the rest of the world did not want the sort of cheap 'plonk' that they had hitherto been producing in bulk. What did begin to sell well, in very small quantities at first, were distinctive, freshly-flavoured, reasonably priced wines made from recognizable classic European varieties.

It was not until the democratic period of the 1990s that wine export really took off in Chile when the neoliberal model was augmented by a new desire to add value to exports. ${ }^{10}$ In this regard, there was a significant effort to improve the quality of Chilean wines. As we see later in this paper, this also involved an explicit effort to differentiate production from other New World producers, through the cultivation of red wine varieties and in particular Carménère. As Argentina has not undergone a land reform similar to that which took place in Chile, many of the large estates that had thrived under colonialism and persisted in the import substitution industrialization (ISI) period remained and these became the basis for the newly outward oriented industry based on quality. Increasingly, however, and to a greater extent than was the case in Chile, foreign capital, particularly from Spain, entered the economy to exploit Argentina's considerable comparative advantage in wine production based on a range of increasingly specialized and high-quality wines as well as relatively low labour and land costs. 
For Argentina, it was the American market that was important. Here Chardonnay or Cabernet Sauvignon wines could be sold at a very competitive price to an alternative from California. Importantly, these wines were marketed in a similar way to Californian wine: they used varietal labelling rather than confusing European regional branding (Burgundy, Bordeaux or Rioja) and they also seemed to offer an evenness of quality from one vintage to the next. Chile straddled both the UK and USA markets, ${ }^{11}$ whilst New Zealand looked more to the UK market where it found, almost by accident, a niche. Australian wine had been successful on the UK market in a similar way to Chile and Argentina: good value, even quality, simple varietal wines. What distinguished the New Zealand niche in that market was a particular variety - Sauvignon Blanc - that was being produced from the Marlborough region that offered a highly distinctive and uncomplicated flavour profile.

\section{Quantitative shifts in production and export of wine - new markets in the Old World}

These export imperatives drove the industries in new directions. Decline was arrested in New Zealand at virtually the same time as the vine pull. Indeed some growers may have taken the opportunity to take the government subsidy to remove their old vines of varieties such as Müller Thurgau when others (or, perhaps, even they themselves) chose to plant or replant in varieties such as Chardonnay and Sauvignon Blanc. In Chile, there was decline in some areas but the presence already of classic varieties made the shift to export production somewhat easier. In Argentina, however, the decline was more marked and the recovery slower.

An already well-supplied domestic market seemed to be shifting to more sophisticated tastes and dabbling with imported wines. Overseas, though, there were literally millions of wine consumers seeking good value alternatives to French, Italian, Spanish and Californian wines. Figure 2 shows how the production of wine in the three countries shifted markedly towards exports during the 1990s and 2000s. Exports accounted for nearly all the growth of the industries in the three countries, while domestic consumption of local wines was sluggish at best, and declining at worst. The expansion of the wine industries of the three countries in the first decade of the 2000s has been remarkable. Area planted in grapes has risen in all cases (see Figure 1) and wine production and exports have risen in step (Figures 2, 3 and 4).

Although the expansion of New Zealand wine production was relatively more dramatic than the other two, globally it remained a small player. ${ }^{12}$ Nonetheless New Zealand wine exports revealed an important export strategy. The New Zealand Wine Institute, the industry body, was determined that the 
Journal of New Zealand Studies

Figure 2: Wine exports and production in New Zealand, millions litres, 1989-2009

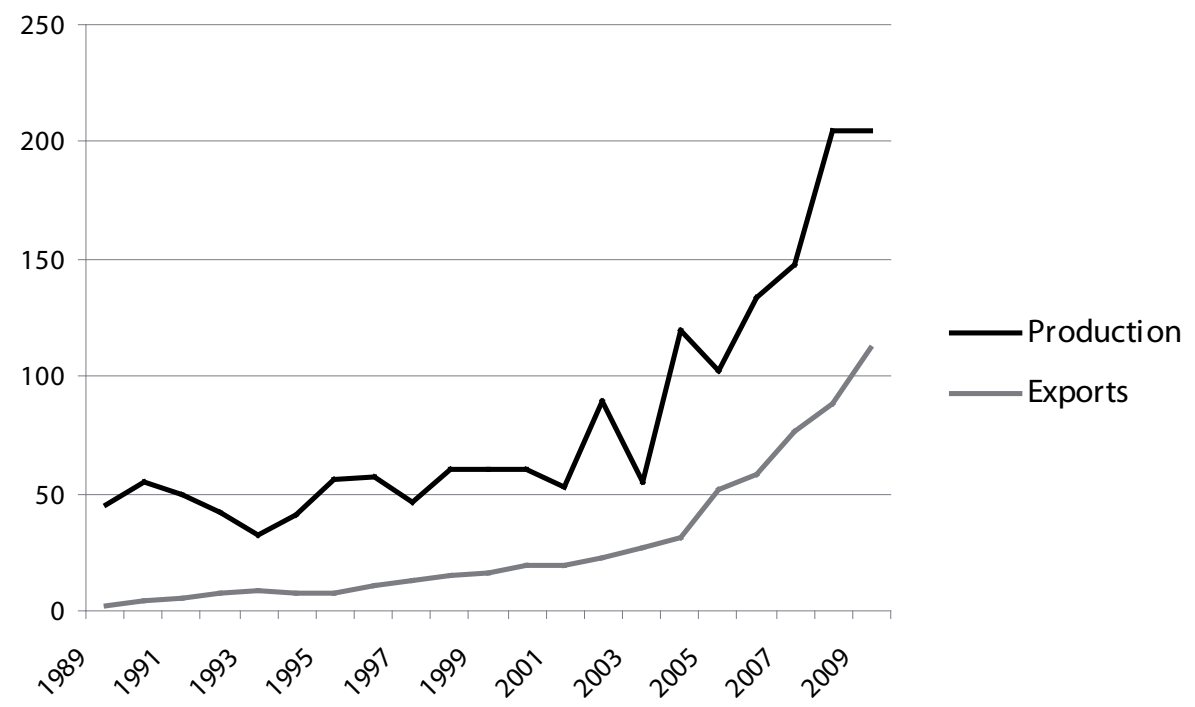

Source: OIV (2011)

Figure 3: Wine exports and production in Chile, millions litres, 1989-2009

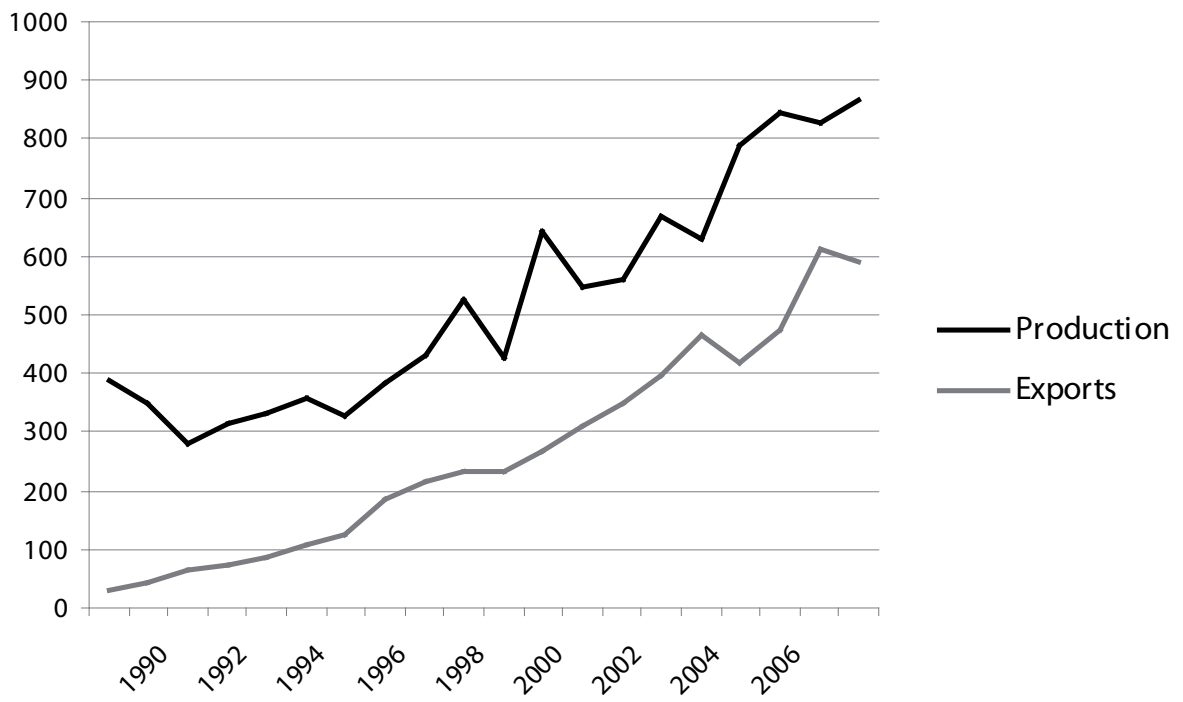

Source: OIV (2011) 
Figure 4: Wine exports and production in Argentina, millions litres, 1995-2009

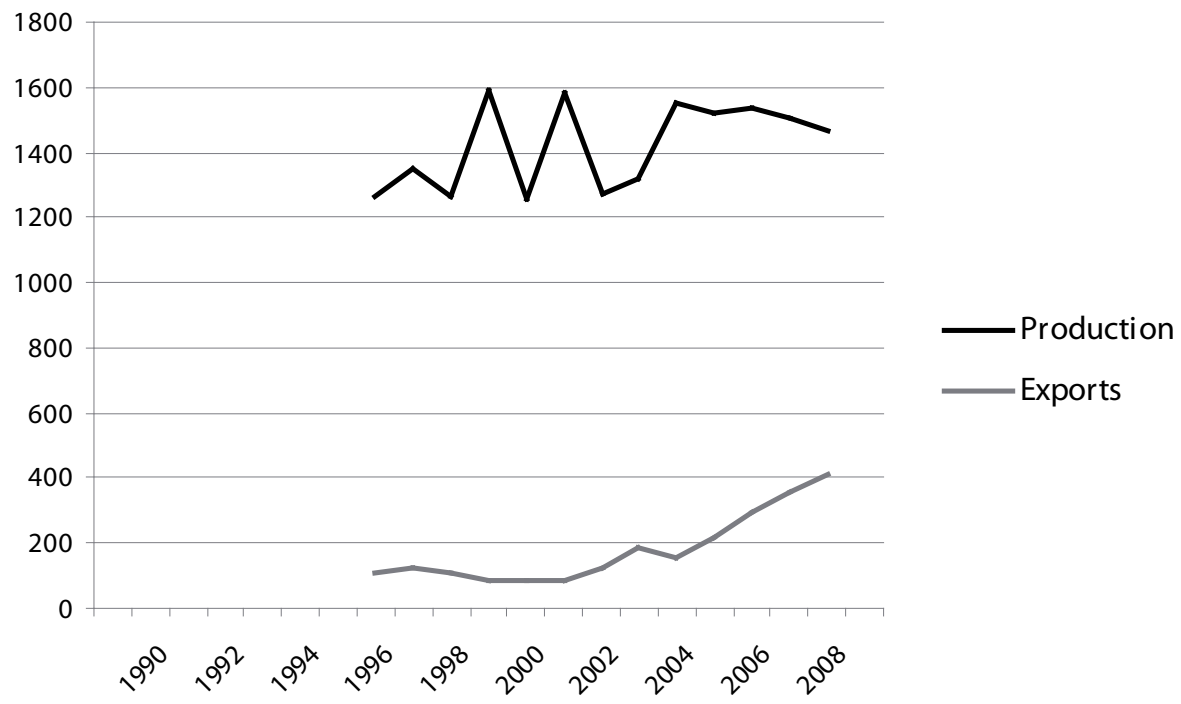

Source: OIV (2011)

New Zealand wine brand should be associated with quality and relatively high prices. Indeed, for many years, New Zealand wine could claim to receive the highest average price per bottle on the UK market. This strategy depended on its niche as a producer of distinctive varietal-based wines: wines which were sold only in bottles, not in bulk containers such as casks, and wines that were always identified by variety and year (as well as country), not generic 'mixed' variety/vintage products. However, this latter approach did not suit the other two, especially Chile. ${ }^{13}$ It found that it could compete well in markets such as the USA and UK with good value varietal wines whilst also, as a very efficient producer of low cost wine, shipping much of its wine in bulk to emerging markets such as China ${ }^{14}$ where it could tempt new wine consumers with a cheap but reasonable-quality product. Argentina was similarly engaged in bulk wine production but it began to realize some real benefits from moving towards the upper end of the market. ${ }^{15}$

As an interesting footnote to the export of bottled and bulk wine from the three countries, we have seen trade occur amongst the three and there has been some 'co-production'. Although New Zealand wine consumption has been fairly static, some local wine companies have found that very high demand for their products overseas has led to shortfalls in their portfolio of wines offered domestically, particularly at the lower end of the market. 
Anxious to maintain supplies to their local retailers and also capitalize on their brand locally, companies have occasionally blended New Zealand wine with that from South America. Although identified as such in small print on their labels, the passing off of imported wine from Chile under a New Zealand wine brand, represents an interesting example of how the wines of the countries can be complementary - good value South American red wine can help New Zealand wine companies retain market share domestically. This represents one example of co-opetition upon which we expand below.

\section{Qualitative shifts in production and export of wine - Old World varieties made new}

A number of qualitative shifts have accompanied the aggregate growth of the industries and the turn to more intense and value-added export production, resulting in parallel transformations. These have involved marked changes in the varietal mixes of the national vineyards, the emergence of signature wines and both regional spread and deepening.

With the turn from domestic and low-cost export to value added exportorientation or neostructuralism has come a major change in the mix of varieties grown (Figures 5, 6, 7). There are two key trends to observe here. First, is the decline in all three cases of the old bulk varieties (País and Muscatel in Chile; Pedro Giménez and Torrontes Riojano in Argentina; and

Figure 5: Land area by wine grape variety (hectares) Argentina

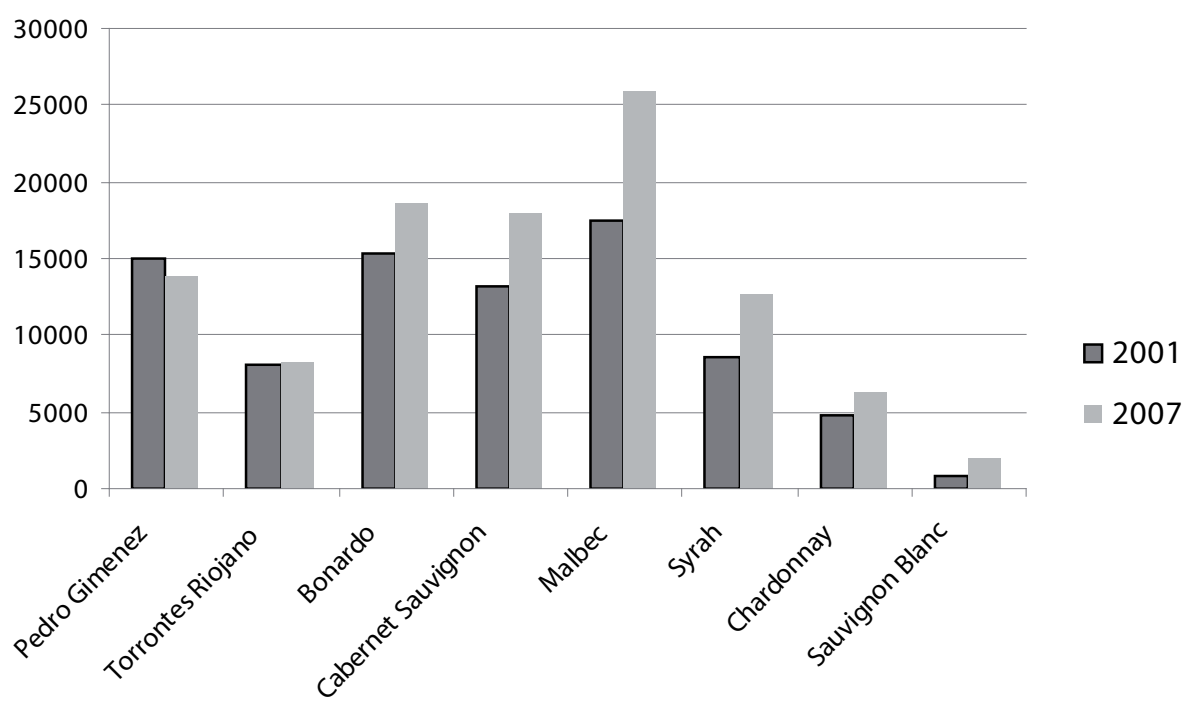

Source: OIV (2011) 
Between Competition and Co-operation

Figure 6: Land area by wine grape variety (hectares) Chile

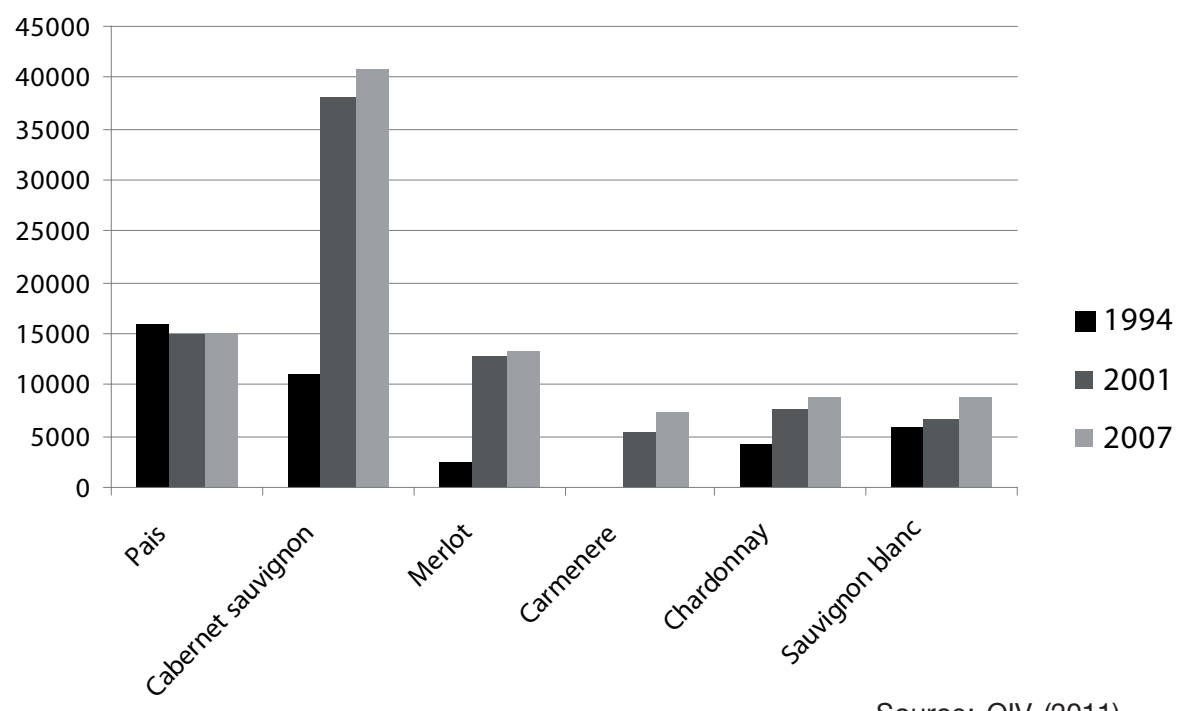

Source: OIV (2011)

Figure 7: Land area by wine grape variety (hectares) New Zealand

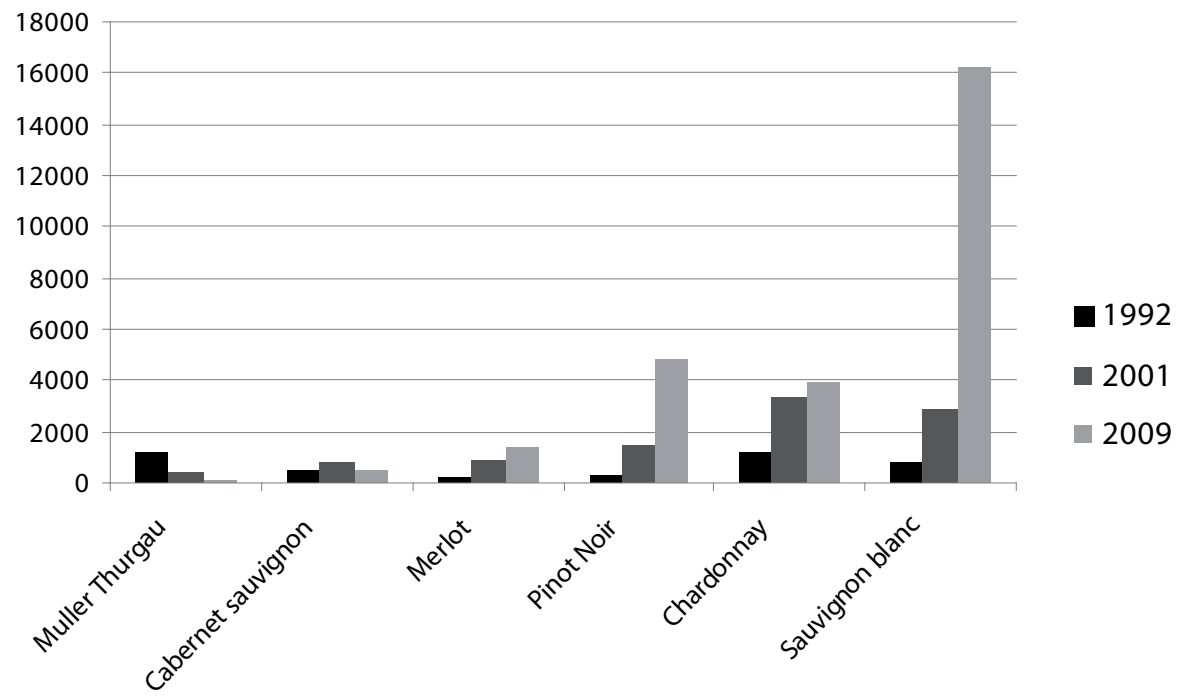

Source: OIV (2011) 
Müller Thurgau in New Zealand - virtually none of which was exported) to be replaced by a range of classical varieties, including Chardonnay, Cabernet Sauvignon, Merlot and Pinot Noir, increasingly in demand from both international and domestic consumers. In New Zealand, for example, we can see that Müller Thurgau has fallen from over $20 \%$ of the national vineyard in 1990 to a bare $0.25 \%$ twenty years later. In Chile, País declined from $13.8 \%$ in 1994 to $8.2 \%$ in 2007 . Chardonnay is perhaps the most ubiquitous of the classical varieties and was one of the first to emerge in all three cases - a pattern matched by Cabernet Sauvignon.

Particularly interesting to note as a second trend has been the emergence of signature varieties. These have been different in each case but in all they have come to identify the wines of Chile, Argentina and New Zealand globally. For New Zealand it has been Sauvignon Blanc. This variety of wine made in a particular style has neatly come to symbolize the brand of New Zealand wine as fresh, vibrant, distinctive and 'clean'. Produced in the Marlborough region it seems to develop a flavour profile that it is virtually unique - it has proved almost impossible to replicate these exact flavours in other regions or countries. The enormous success of Marlborough Sauvignon Blanc has fundamentally driven the expansion of the New Zealand industry in the past twenty years. Over this time there has been a change from when Marlborough accounted for 28.8\% and Sauvignon Blanc 12.9\% of the country's wine production in 1992 to $48.9 \%$ and $50.7 \%$ respectively in 2009. This dominance of a single variety and a single region has been associated with impressive rates of growth and development, yet it is also now showing signs of a dangerous over-dependence. ${ }^{16}$

Whilst not as dramatic as Marlborough Sauvignon Blanc, Chile and Argentina have similarly developed signature wines. In Chile, a quirk of nature and history resulted in the rediscovery of a variety - Carménère - that was thought to have virtually been wiped out by phylloxera in its native France in the nineteenth century. ${ }^{17}$ It was not recognized as this variety in Chile - being thought of as a type of Merlot - until genetic testing established it as such in the mid 1990s. Since then, the ability of phylloxera-free Chile to produce this variety has given it a product that is highly distinctive and one that is sought by consumers wanting an alternative to similar Bordeaux-style red wines. As a result, planting of new Carménère vineyards has proceeded apace. It is still a long way from replacing the dominant Cabernet Sauvignon and Merlot varieties which form the bulk of Chilean red wine exports; it does not contribute significantly to the lowerprice end of the market but, rather, it is what champions Chilean red wines at the upper end.

Similarly, the wines of Argentina are increasingly identified globally by red wines, in particular the Malbec variety from Mendoza. Like Carménère, 
this is a minor Bordeaux variety but one which seems to find particular expression elsewhere. Mendoza winemakers, backed by expert overseas advisors such as Michel Rolland, have tried to, and largely succeeded in, developing this variety as a singular high quality wine. Again it helps establish Argentinian wine with a distinctive place on the crowded shelves of wine retailers worldwide. As with Chilean Carménère, it is not as dominant in the country's vineyards as Marlborough Sauvignon Blanc but its rise is highly significant.

This varietal re-orientation of the respective wine economies presents an interesting economic strategy based on the distinctive geographies. As New World exporters, each of the economies has come to inhabit overlapping competitive space in the global wine market. The witting development of signature varieties that exploit the particularity of place take the production 'upscale' and prevent a head-on clash of interests. The carving out of these niches can be seen as an attempt to establish parallel lines in the same lucrative markets. These products are complementary as New World success in one variety from one particular country helps raise the profile of the others. It is in this sense that we can interpret the recent evolution of the Southern hemisphere as characterized by competition and cooperation at the same time - or co-opetiton..$^{18}$ Whilst each of these signature ranges has come to be associated with the respective producing countries and in some ways to be indicative of the geography of those places, each is in fact a classic European variety that has been transplanted, adapted and sold back to the 'core' of the world market. This interesting reversal of the direction of economic flows says something about the reconfiguration of the core and periphery in the world economy as old geographies are made new.

\section{Geographic shifts in the production of wine - new regional specializations}

Another aspect of these transformations in all three countries has been the changing geography of wine production, involving both intensification and expansion. The moves to quality export production, the adoption of classical varieties and the search for higher quality products have had immediate spatial implications. The former regime of cheap bulk-wine production for the domestic production suited certain environments, especially those with fertile soils, good water availability and warm temperatures. Here high yields of grapes could lower production costs and ensure constant supply. This suited regions such as the flat alluvial soils found variously in the Central Valley of Chile (around places such as Curicó and Rancagua), the plains of Hawke's Bay and Gisborne in New Zealand and the lower irrigated plains around Mendoza in Argentina. However, premium wine production has demanded different terroir. Grape vines which have to struggle more 
in poorer soils, in places where water is not always abundant or where temperature variations are greater are thought to produce more intense and concentrated fruit flavours. Yields are lower but the quality of the juice is deemed to produce better and more distinctive wines.

The search for such favourable environments for high-quality grape production has led to significant development of core wine-producing regions. Marlborough has developed over the past 30 years from a region where almost no grapes were grown at all to a highly specialized wine region where vineyards dominate the landscape. ${ }^{19}$ It is matched in Chile though not to quite the same extent. The Colchagua region has become associated with quality red wine production (along with the Maipo Valley) and expansion of vineyard area there has been marked. In Argentina, the Mendoza region continues to dominate the country's industry ${ }^{20}$ but within this large region there have been differences with higher sub-regions such as the Uco Valley ${ }^{21}$ (with less fertile soils and cooler climates) experiencing significant expansion whilst others have been steady or declined. Furthermore, within these core regions and subregions there have been some important and more subtle changes. Matching the search for favourable regions has been a quest to find the best sites: vineyards situated on particular patches of soil, or in microclimates or on slopes with a particular orientation to the sun. Whether in Marlborough, Colchagua or Mendoza, there has been the gradual shift of the premium vineyards away from the alluvial flats towards steeper hillsides and particular sites.

Finally, in terms of geographical expression, there has been a development of completely new wine regions in the past 30 years. This has resulted often from the development of new varieties that seem to suit particular places more than the former traditionally-cultivated regions. There are examples in all three countries. In Chile, the development of the Casablanca region between the major cities of Valaparaíso and Santiago has been notable. ${ }^{22}$ This region which grew very few grapes formerly has a cooler climate than the Central Valley and has been found to produce white grape varieties of very good quality, in particular Chardonnay and Sauvignon Blanc. Flavour intensity is greater than in the warmer regions and Casablanca has become the centre of Chile's premium white wine production. In New Zealand, the Pinot Noir variety has become the country's main red wine variety but this seems to suit cooler and more marginal climates than the Hawke's Bay region, hitherto the dominant region for red (principally Bordeaux style) wine production in the country. Pinot Noir has succeeded in a number of cooler minor regions, such as Martinborough and Waipara, as well as Marlborough. However, it is in the country's southern-most region in Central Otago that Pinot Noir has come to find a particular home. As with Casablanca, the expansion of grape growing has been recent and dramatic: in 1992 there 
were just 25 hectares planted in grapes in Central Otago but by 2009 there were 1532 hectares. Furthermore, the concentration on Pinot Noir has been exceptional: $78 \%$ of the 2009 area was planted in this variety - the most specialized wine region in New Zealand. In Argentina, a parallel example of new region development can be found in the Uco Valley. This is not an entirely new region but it is noticeable that the upper reaches of this area to the south of the town of Tunpungato have seen considerable expansion with a number of new and modern wineries producing Malbec and other premium varieties. ${ }^{23}$

Thus given the shift to more geographically-distinct varieties we have seen both 'upscaling' in production where smaller and more specialized levels of production in unique places are developed ${ }^{24}$ together with an expansion of the wine production frontier, and often the agricultural frontier more generally, into formerly unexploited territory. This is an example of the evolution of parallel regional economies within national territories in ways that prevent wine producing places from clashing in competitive space. This mirrors the process of heterogenization that is happening at the global level discussed in the previous section.

\section{Capital and labour - new modes of production from old and new sources}

The expansion of the wine industries of Chile, Argentina and New Zealand have demanded new methods of production and new sources of land, labour and capital. To some extent, these have come from the well-established resources of existing companies and communities. But in many cases they have required new sources to be tapped with capital and even labour coming from overseas. In this way, these wine producing regions on the periphery of the global economy have been linked to the centre not just through the flow of wines to the markets of Europe and North America but also through the reverse flow of capital to invest in places that are now part of a global portfolio of wine brands for international beverage corporations.

New Zealand has seen perhaps the most significant involvement of global capital. For many years, the expansion of the industry in New Zealand was driven by a small number of local companies. The most significant was Montana. This company grew rapidly and gradually absorbed its rivals, in particular the Corbans group in 2000. By this time it had come to account for over half of the country's production. However, Montana soon succumbed to foreign interests as it sought to both expand its production and secure access to overseas markets. It sold first to Allied Domecq, which was in turn bought out by the giant Pernod Ricard group. ${ }^{25}$ Also prominent in the New Zealand industry is the Constellation Brands stable of brands and the Louis Vuitton Moët Hennessey (LVMH) group which owns the iconic Cloudy Bay 
brand. In Argentina, as noted previously, the imprint of foreign investment is also noticeable. There are French, Spanish and American companies who have invested heavily in the Mendoza region and are at the forefront of the Malbec development and its marketing worldwide. In Chile, foreign companies such as Torres, Château Lafite and Robert Mondavi are found, ${ }^{26}$ adding Chilean Carménère and other premium red wines to the stable of brands. However, in neither Argentina nor particularly Chile is the extent of foreign investment and ownership of the wine industry as widespread as in New Zealand. Local companies, such as Montes in Chile ${ }^{27}$ retain a prominent place. Nonetheless, the incorporation of wineries and vineyards from all three in the investment portfolios of major global wine and beverage companies does reflect the closer integration of the industry worldwide. It also creates common interests and a likely increase in coordination in terms of the way national industries are diversified in parallel in the future in terms of wine styles.

A further aspect of capital investment in all three countries is the presence of new local capital. Alongside long-established wine companies and investors is a breed of investors in the industry that have generated wealth from outside the industry but sought to invest in wine perhaps as a way of attaching themselves and their reputations to a glamorous industry, sometimes far removed from their main source of wealth in sectors such as retailing, banking or in one spectacular Chilean example, arms dealing. ${ }^{28}$ To an extent, these local forms of capital act alongside global capital to invest in, and profit from, the establishment and consolidation of new wine regions which trade on notions of terroir ${ }^{29}$ and regional distinctiveness. ${ }^{30}$

The demand for labour in the wine industry has grown not only because of the absolute growth of the industry but also because the qualitative shift has demanded more labour-intensive methods, such as hand picking of grapes, hand pruning of vines and more intensive wine making techniques. In these cases mechanization has been supplemented by deliberate use of more intensive use of manual labour, whether of the unskilled (harvesting and pruning) or skilled (winemaking) forms. In South America, this heightened demand for labour has been met from existing sources, seemingly from local rural labourers or migrant labour gangs that mix involvement in the wine industry with other rural sector work or their own subsistence holdings. The extent to which the wine industry contributes new livelihood options and better prospects for these groups on one hand, or, alternatively, merely exploits this cheap pool of labour is yet unclear and begs further research. In New Zealand, however, the demand for labour in the vineyards has long outstripped local supply. Contract labour gangs from Southeast Asia are often used to supplement local seasonal labour during harvesting and pruning seasons. Notably, however, the high demand and importance of 
the industry has spurred a degree of government support in the form of a seasonal migrant labour scheme that promotes the recruitment of workers from Pacific Islands to work in New Zealand vineyards and farms. ${ }^{31}$

It is perhaps interesting to note that whilst there is no obvious connection or competition in terms of unskilled labour in the three wine industries, there is a thread of labour that does appear across them. Winemakers are sought after worldwide and those from the New World are often seen as being at the vanguard of modern techniques and the production of desired wine styles. These are people who become "flying winemakers' ${ }^{32}$ overseeing vintages in different parts of the world. Thus it is not uncommon to find a New Zealander making Sauvignon Blanc in Casablanca or Chilean trainee winemakers working in Marlborough.

\section{Conclusions}

The wine sectors of Argentina, Chile and New Zealand have divergent histories and are significantly different in terms of their factor endowments. However, they have come to occupy parallel competitive spaces in the contemporary economy. Although the three sectors are of a different scale these divergent antecedents have not prevented the coming together of the sectors. Beginning in the 1960s there was a shift to structuralist-informed ISI and then later, in the late 1970s and early 1980s, to unfettered neoliberalism. This later development shifted the industries in concert from ones which were characterized by relatively large-scale bulk production for domestic markets to ones that focused on low-price export orientation. The rolling out of neoliberalism across the countryside had a very negative impact on the wine industry in all three cases. What is particularly remarkable is that all three bounced back from this to become successful exporters with positive reputations on the global markets.

As the 'easy' phase of neoliberalism became exhausted in each country there was a witting shift to strategies of value-added production, sometimes termed neostructuralism. This occurred first and most rapidly in New Zealand around the end of the 1980s. In the mid-1990s there was a qualitative shift in Chile and later Argentina emulated the success of the former. This shift in productive orientation was characterized particularly by the move to specialized varieties that came to signify particular countries and, increasingly, regions within those countries. Ironically, the varieties were classic European grapes. This development saw the evolution of parallel sectors competing for the same global space but in ways that did not directly overlap. At the same time other forms of co-operative activity including research and development, winemaking, and bulk blending occurred. Below the national scale we also began to see a crystallizing of national space into more specialized regions, each producing signature varieties based on 
investment from both embedded local capital and increasingly footloose yet coordinated global sources.

The outcome of these competitive shifts has been the development of three very successful export sectors in terms of the quantity and quality of exports. Although their scale is vastly different, the trajectory has been remarkably similar in outline form - yet the details of the respective evolution vary. Growth has been most impressive in Chile and New Zealand, whereas in Argentina the relatively large internal market means that exports are of less significance. However, the sectors have helped diversify these primary product-dependent countries away from over-reliance on one or two products - a situation that characterized them all during the colonial period and in the immediate postcolonial times. Furthermore, success in one wine sector has had a demonstration effect and led to complementary outcomes in the others - as the reputation of New World wines rises in one place, others enjoy positive externalities. One caveat to this broadly positive story is important, however; whether these beneficial macroeconomic impacts have flowed down to labour and the localities that host the newly vibrant wine sectors is an open question and should form the basis for further research.

Overall, the parallel evolution of the three sectors has led to a dialectical process common in the context of globalization whereby an increasingly homogenized global market has stimulated the creation of increasingly heterogeneous space. This has been achieved by investment from a combination of local and global capital that has worked in concert to ensure this parallelism through the development of niche-based production systems that trade on their geographical distinctiveness at successive scales. This complementary differentiation suggests that parallel sectors that do not clash can be carved from economies that should intuitively compete where purposeful intervention and co-operation is encouraged. This assertion may be true for sectors beyond the wine industry and should therefore be explored as a way forward for further interaction in the context of these three Southern hemisphere economies.

1 G. Banks and J. Overton, 'Old World, New World, Third World: Reconceptualising the Worlds of Wine', Journal of Wine Research (JWR), 21, 1 (2010), pp.57-75.

2 E. Challies and W.E. Murray 'Towards Post-Neoliberalism? The Comparative PoliticoEconomic Transition of New Zealand and Chile', Asia Pacific Viewpoint (APV), 49, 2, pp. 228-43.

3 W.E. Murray and E. Challies, 'New Zealand and Chile - Partnership for the Pacific Century?', Australian Journal of International Affairs, 57, 1 (2004), pp.89-103.

4 In the second half of the nineteenth century, European vineyards were ravaged by the phylloxera outbreak. Some varieties were virtually lost at this time. Chile remains the 


\section{Between Competition and Co-operation}

only major wine-producing country where phylloxera is not present and where old varieties can grow on their own rootstock.

5 Steve Stein, 'Grape wars: Quality in the History of Argentine Wine', in G. Campbell and N. Guibert, eds, Wine, Society and Globalization: Multidisciplinary Perspectives on the Wine Industry, New York, 2007, pp.99-117.

6 Keith Stewart, Chancers and Visionaries: A History of Wine in New Zealand, Auckland, 2010.

7 Stewart (ibid., pp.334-6) argues that the vine pull scheme was actually used to benefit the large corporate wine producers who were released from their unprofitable contracts with growers. Most vineyards destroyed were on the land of contract growers and some $25 \%$ of the country's total vineyard area was uprooted.

8 R.N. Gwynne, 'Export-Orientation and Enterprise Development: A Comparison of New Zealand and Chilean Wine Production', Tidjschrift voor Economische en Sociale Geografie, 97, 2 (2006), pp.138-56.

9 E. Giuliani, C. Pietrobelli, and R. Rabellotti, 'Upgrading in Global Value Chains: Lessons from Latin American Clusters', World Development (WD), 33, 4 (2005), pp.549-73; S. Ponte and J. Ewert, 'Which Way 'Up' in Upgrading? Trajectories of Change in the Value Chain for South African Wine', WD, 37, 10 (2009), pp.1637-50.

10 J.M. Benavente, 'Wine Production in Chile', in V. Chandra, ed., Technology, Adaptation and Exports: How Some Developing Countries Got it Right, Washington DC, 2006, pp. 225-42.

11 Gwynne, 'Export-Orientation and Enterprise Development'; R.N. Gwynne, 'Governance and the Wine Commodity Chain: Upstream and Downstream Strategies in New Zealand and Chilean Wine Firms', APV, 47, 3 (2006), pp.381-95; R.N. Gwynne, 'UK Retail Concentration, Chilean Wine Producers and Value Chains', The Geographical Journal (GJ), 174, 2 (2008), pp.97-108.

12 J. Barker, N. Lewis and W. Moran, 'Reregulation and the Development of the New Zealand Wine Industry', JWR, 12, 3 (2001), pp.199-221.

13 W. Foster, A. Beaujanot and J.I. Zúñiga, 'Marketing Focus in the Chilean Wine Industry', JWR, 13, 1 (2002), pp.35-42.

14 C. Chi, 'Chile Leads Bulk Wine Charge to China', Wine Business International, 5 February 2008, http://www.wine-business-international.com, accessed 10 September 2009.

15 G.A. McDermott, 'The Politics of Institutional Renovation and Economic Upgrading: Recombining the Vines that Bind in Argentina', Politics and Society, 35, 1 (2007), pp.103-43.

16 R. Young, 'Sauvignon Plonk - Bad News for Wine', Dominion Post, 13 October 2009.

17 J. Overton and W. Murray, 'Playing the Scales: Regional Differentiation in the Chilean Wine Industry', Journal of Rural Studies, 27, 1 (2011), pp.63-72. Organisation Internationale de la Vigne et du Vin (OIV) (2011) Situation et Statistiques du Secteur Vitivinicole Mondial (annual, 1999-2007) http://www.oiv.int/oiv/info/enstatistiquessec teurvitivinicole\#secteur, accessed 1 August 2011.

18 W.E. Murray and E. Challies, 'Beyond Neoliberalism in the Semi-Periphery? Bilateral Relations between New Zealand and Chile', APV, 47, 3 (2006), pp.351-95.

19 D. Hayward and N. Lewis, 'Regional Dynamics in the Globalising Wine Industry: The Case of Marlborough, New Zealand', GJ, 174, 2 (2008), pp.124-37. 


\section{Journal of New Zealand Studies}

20 A. Morris, 'Globalisation and Regional Differentiation: The Mendoza Wine Region', JWR, 11, 2 (2000), pp.145-53.

21 M. Rolland and E. Chrabolowky, Wines of Argentina, Buenos Aires, 2008.

22 F. Pino, 'Transformaciones del paisaje rural derivadas de la actividad vitivinícola del Valle de Casablanca en el contexto de la globalización' Publicación Electrónica, X Jornadas Cuyanas de Geografía; J. Overton, W. Murray and F. Pino, 'The Remaking of Casablanca: The Sources and Impacts of Rapid Local Transformation in Chile's Wine Industry', JWR (in press).

23 Rolland and Chrabolowky.

24 Overton and Murray, 'Playing the Scales'.

25 Stewart.

26 Benavente, p.228.

27 J. Ross, Where Angels Tread: The Story of Viña Montes, Santiago, 2006.

28 J. Overton, W. Murray and G. Banks, 'The Race to the Bottom of the Glass? Wine, Geography and Globalisation', Globalizations (in press).

29 J.E. Wilson, Terroir: The Role of Geology, Climate, and Culture in the Making of French Wine. London, 1998; W. Moran, 'Terroir - the Human Factor', Australian and New Zealand Wine Industry Journal, 16, 2 (2001), pp.32-51; S. Charters, Wine and Society: The Social and Cultural Context of a Drink, Oxford, 2006.

30 G. Banks and S. Sharpe, 'Wines, Regions and Geographic Imperative: The Coonawarra Example', New Zealand Geographer, 62, 3 (2006), pp.173-84; G. Banks, S. Kelly, N. Lewis and S. Sharpe, "Place "From One Glance": The Use of Place in the Marketing of New Zealand and Australian Wines', Australian Geographer, 38, 1 (2007), pp.15-35; J. Overton, 'The Consumption of Space: Land, Capital and Place in the New Zealand Wine Industry', Geoforum, 41, 5 (2010), pp.752-62.

31 C. Beer and N. Lewis, 'Labouring in the Vineyards of Marlborough: Experiences, Meanings and Policy', JWR, 17, 2 (2006), pp.95-106.

32 A. Lagendijk, "Global "Lifeworlds" Versus Local "Systemworlds": How Flying Winemakers Produce Global Wines in Interconnected Locales', Tidjschrift voor Economische en Sociale Geografie, 95, 5 (2004), pp.511-26. 